Litinfinite Journal

ISSN: 2582-0400 [Online]

CODEN: LITIBR

Vol-1, Issue-2 (2 ${ }^{\text {nd }}$ December, 2019)

Page No: $45-47$

DOI: 10.47365/litinfinite.1.2.2019.45-47

Section: Interview

\title{
An interview of Vinay Sharma
}

\author{
Sreetanwi Chakraborty \\ Assistant Professor \\ Amity Institute of English Studies and Research \\ Amity University Kolkata \\ Email Id: schakraborty3@kol.amity.edu
}

\begin{abstract}
This interview mainly highlights the current trends in the field of Indian English play, the stage and different theatrical aspects. Vinay Sharma is an actor, a theatre director and a writer who has a major role to play in the development of the Padatik theatre group in Kolkata. Here he talks about his theatrical motivation, inspiration and how the whole concept of proscenium theatre has undergone a major change in the last 20 years. Moreover, he also talks about instinct and intuition while channelizing the creative potential in any play. The overall interview talks about the changing scenario with reference to theatre, performance, stage and audience.
\end{abstract}

Keywords: Indian Theatre, Theatre, Audience, Indian English Drama, Proscenium

Vinay Sharma: Vinay Sharma is an actor, director, and a writer who started his career in Padatik theatre based in Calcutta since 1981. His imaginative and creative thoughts were amply portrayed in major plays and he received critical appreciations for playing some major roles under well-known directors like Shyamanand Jalan, Rodney Marriot, and Usha Ganguly. His production of 'Atmakatha' starring Kulbhushan Kharbanda featured at the 8th Theatre Olympics. 'Ho sakta hai', 'Do Aadmi Do Kursiyaan', 'Camera Obscuras', 'Yahan' and 'Yawah Goi' are some of the prominent plays written by Sharma. Apart from that, he has also performed the monologue 'Mark Twain: Live in Bombay' written by the Canadian playwright Gabriel Emmanuel in 2018 and it was shortlisted for the TLM New Writing Award 2006 and The Bridport Poetry Prize 2017. Known for his consummate craftsmanship, innovative stage presence and growing contribution to Indian theatre, Sharma is definitely one of the most-recognized names not just in Kolkata, but also worldwide. His interview with Prof. Sreetanwi Chakraborty follows thus:

Q: It might seem to be a clichéd question, but still, what inspired you to join theatre?

A: My father was a stage actor in the Bangla professional theatre from the nineteen sixties till late eighties. His stage name was Sarbendra. I grew up watching his work on the North Calcutta theatre circuit. My alma mater Don Bosco, Park Circus also encouraged students to

Note: This is an interview and there is no citation or works cited required. It is a live interview taken by Sreetanwi Chakraborty, Chief-Editor of Litinfinite Journal. 
Litinfinite Journal

ISSN: 2582-0400 [Online]

CODEN: LITIBR

Vol-1, Issue-2 (2 ${ }^{\text {nd }}$ December, 2019)

Page No: $45-47$

DOI: 10.47365/litinfinite.1.2.2019.45-47

\section{Section: Interview}

develop their dramatic potential. Mr. Frederick Gomes, our Drama teacher was a gentle mentor. So it was a natural progression I suppose.

Q: Why did you join Padatik? What actually inspired you to go for group theatre?

A: Enthused by some success at the British Council Inter-School Competition, I answered Padatik's call for auditions in 1981 and was privileged to find a remarkable teacher in my Guru-to-be Shyamanand Jalan. I had no understanding of group theatre then. It was just exciting for a young actor to be in a space where one was exposed to the ideas and works of some of the most committed and celebrated theatre and dance practitioners of the time like Satyadev Dubey, Badal Sircar, Probir Guha, Fritz Bennewitz, Ram Gopal Bajaj, Birju Maharaj, Guru Kelucharan and writers like Vijay Tendulkar, Satish Alekar, Govind Deshpande et al. who collaborated with or visited, workshopped or lectured at Padatik. Shyamanand ji also curated the International Martial Arts Seminar in Calcutta during that period which hosted several international theatre stalwarts at Padatik, including the likes of Eugenio Barba and Richard Schechner. What more inspiration could one need?

Q: How do you think the concept of proscenium stage has changed in the last 20 years?

A: The proscenium stage has naturally moved on to embrace newer technology; it has become more entertainment-based and audience-conscious; the theatre of words has, to a large extent, receded and made way for a more visual, sometimes more extravagant and consequently, at times, a more vacuous theatre.

Q: You have to juggle between being an actor and a director. How do you enjoy each role? And what can be the probable 'stress' points?

A: Acting requires that you sink deep into yourself in looking for your part.

Direction demands that you sink into the 'Work' itself to seek more than the sum of the parts. I don't juggle between the two. After so many years the two have become mutually inclusive. I suppose the main 'stress' point is communication - that agonizing process of 'conveying' to another, or even to your own self that which you may not even find adequate words to describe. But at the best of times 'stress' can become a tool that propels that 'conveyance', fuels your creativity, makes you try harder. So it is frequently a positive component. I would even go as far as to say it is a procedural necessity.

Q: What exactly does art direction entail? In this connection, how do you make use of technology for all the plays that you perform or direct?

A: For me it's a subjective thing. It requires instinct, intuition, and an especial awareness that a 'work' of theatre is a universe in itself and must contain plausible reasons that explain its nature, its design, its function to performers and viewers through overt or covert signifiers. I use any available technology, very often 'found material' to satisfy these very requirements. Q: Satire is one of the most integral components of Mark Twain: Live in Bombay. You seem to have played the role with aplomb. How was the feeling?

Note: This is an interview and there is no citation or works cited required. It is a live interview taken by Sreetanwi Chakraborty, Chief-Editor of Litinfinite Journal. 
Litinfinite Journal

ISSN: 2582-0400 [Online]

CODEN: LITIBR

Vol-1, Issue-2 (2 ${ }^{\text {nd }}$ December, 2019)

Page No: $45-47$

DOI: 10.47365/litinfinite.1.2.2019.45-47

Section: Interview

A: I love plays which weigh words with care. Gabriel Emanuel's nuanced script projects

Twain's craft, his views and his spirit with great relevance. So it was a very satisfying experience.

Q: Pieces is a play where we find a solo act about women in love. How did you fathom and articulate this female consciousness so well?

A: When you select apt passages from great writers like Chekov, Strindberg, Woolf etc your task can become easier. But of course to re-contextualize their writings into an 'Everywoman' play text with contemporary resonances did require an observation and analysis of experiences both personal and vicarious.

Q:Elkunchwar's Atmakatha finds Kulbhushan Kharbanda returning to stage after almost two decades. How was the feeling of working with him?

A: Mr. Kharbanda is a consummate director's actor. It was like working with a caring friend who was as invested in the work as you were.

Q:Do you think the range and quality of audience has improved over the years (especially with reference to Indian English theatre)?

A: I do not think a theatre practitioner will ever be able to answer that question objectively. Audiences have always been mercurial and ever capable of surprising us, for the better or for the worse.

Q: Any piece of advice for newcomers?

A: There are no shortcuts in the theatre.

\section{Suggested list of reading}

"Director Vinay Sharma on ATMAKATHA." YouTube. prithvi theatre, n.d. Web. 3 Aug. 2019. <https://www.youtube.com/watch?v=TPS_VplNmAQ>.

"Padatik (Indian Theatre Group) - Wikipedia." Wikipedia, the Free Encyclopedia. Wikimedia Foundation, Inc, n.d. Web. 9 Apr. 2019.

Punjani, Deepa. "Interview With Vinay Sharma : Www.MumbaiTheatreGuide.com." N.p., Web. 17 Jan. 2019.

<https://www.mumbaitheatreguide.com/dramas/interviews/vinay-sharmainterview.asp\#>.

Note: This is an interview and there is no citation or works cited required. It is a live interview taken by Sreetanwi Chakraborty, Chief-Editor of Litinfinite Journal. 